\title{
The implementation of health istithaah to the pilgrims with tuberculosis: a cross- sectional study in Jakarta, Indonesia
}

Ibnu Mas'ud, Ujainah Zaini Nasir, Ceva Wicaksono Pitoyo, Ikhwan Rinaldi

Check for updates

pISSN: 0853-1773 • elSSN: 2252-8083 https://doi.org/10.13181/mji.oa.203517 Med J Indones. 2020;29:198-203

Received: January 23, 2019

Accepted: June 21, 2020

Authors' affiliations:

Department of Internal Medicine, Faculty of Medicine, Universitas Indonesia, Cipto Mangunkusumo Hospital, Jakarta, Indonesia

\section{Corresponding author:}

Ujainah Zaini Nasir

Department of Internal Medicine, Faculty of Medicine, Universitas Indonesia, Cipto Mangunkusumo Hospital, Jalan Pangeran Diponegoro No. 71, Kenari, Senen,

Central Jakarta 10430, DKI Jakarta, Indonesia

Tel/Fax: +62-21-3149704

E-mail: a.uyainah@gmail.com

\begin{abstract}
BACKGROUND Based on the regulation of the Indonesian Ministry of Health No. 15 of 2016 about health istithaah for the Hajj, patients with tuberculosis (TB) can be categorized into ineligible or temporarily ineligible pilgrims. This study aimed to know the characteristics of pilgrims with TB and determined their level of fitness for fulfilling the health istithaah.
\end{abstract}

METHODS A cross-sectional study of pilgrims from Jakarta who were receiving TB treatment during the Hajj in 2018 was conducted with consecutive sampling. The secondary data was collected from the Hajj Integrated Computer Health System 2018, TB registered form, and six-minute walk test (the fitness level data) conducted by the District Hajj Health Team at district health centers in DKI Jakarta and Pondok Gede before the Hajj embarkation in June-July 2018. The questionnaire to the Indonesian Hajj Health Team during pilgrimage was also included as additional data.

RESULTS Thirty-one pilgrims received TB treatment and completed the intensive phase of TB treatment, but 29 pilgrims had no symptoms. Among them, 2 patients had MDR-TB. Most of them were male aged $\geq 40$ years old. Twelve pilgrims with TB have a sufficient fitness. All pilgrims were able to run the pillars of the Hajj.

CONCLUSIONS Pilgrims with TB, including MDR-TB, who had completed the intensive phase with a negative sputum smear test were declared eligible for the Hajj with assistance.

KEYWORDS eligibility, pilgrims, tuberculosis
The pilgrimage is a mandatory worship for Muslims who have an ability to perform this. ${ }^{1}$ More than three million Muslims will gather from around 180 countries during the Hajj season. ${ }^{2}$ Most of the pilgrims will assemble into a musty crowd, share tents or rooms with other pilgrims, undergo tiring rituals, and be sleep deprived. As a result, they are susceptible to illness and those conditions may facilitate the transmission of infectious diseases. The Health Center for the Hajj Ministry of Health Republic of Indonesia reported that airborne transmitted diseases remain the most common diseases among pilgrims, and are the second leading cause of death (31\%) after cardiovascular diseases (CVD) (45\%). ${ }^{3}$ Tuberculosis (TB) is one of the diseases which have a significant high risk of transmission. More than 50\% of pilgrims originated from $85 \%$ of global TB cases region including India, Pakistan, Bangladesh, South Asia, and Africa. ${ }^{1-4}$ In 2016, the number of pulmonary TB detected among pilgrims was 440 new cases and one congregation casualties related to pulmonary TB. 4,5 
In undertaking the pilgrimage, pilgrims are required to have three istithaah namely istithaah maliyah (capable of financial aspects), istithaah amniyah (capable of transportation and security), and istithaah badaniyah (physical ability both physically and mentally). This relates to the series of pilgrimages traditions including seven rounds of circumambulation around the Kaaba (1.4 km in the closest distance to the Kaaba) for Tawaf, Sa'i is jogging from the Safa hill to Marwa seven times back and forth (2.8 km), Wukuf at Arafat, and throwing pebbles (jumrah) in the area of Jamarat $(14.273 \mathrm{~km})$, in addition to the extreme temperature and overcrowded conditions. According to that condition, some pilgrims who have certain diseases such as TB are the government's concern. According to the Ministry of Health Republic of Indonesia No. 15/2016, ${ }^{6}$ istithaah badaniyah establishes the concept of health istithaah. This limits some patients who suffer from totally drug resistance-TB, multidrug resistance (MDR)-TB, or have a positive TB sputum smear as they are classified into a group considered unable to fulfill istithaah requirements. Hence, they are also potentially unable to get along with the fifth pillar of Islam. Apart from TB condition, pilgrims with TB are also required to have a sufficient level of fitness at least with enough or more maximal oxygen consumption $\left(\mathrm{VO}_{2} \max \right) \geq 34.1 \mathrm{ml} / \mathrm{kg}$ body weight/min.

Indonesia as a country with a large Muslim population and a high TB burden endemic, will send a large population of pilgrims in each Hajj season. TB infection data on Indonesian pilgrims are still far from sufficient. Therefore, this study aimed to know the characteristics of pilgrims with TB and determined their fitness levels for fulfilling the health istithaah.

\section{METHODS}

This cross-sectional study was held from posthealth examination of pilgrim candidates to result announcement of the Hajj eligibility which took place in district health centers in DKI Jakarta and Pondok Gede embarkation using consecutive sampling in June 2018July 2018.

This study included the Hajj pilgrims embarked from DKI Jakarta in 2018 aged more than 18 years old who diagnosed with TB from the Hajj Integrated Computer Health System (Sistem Komputerisasi Haji Terpadu Kesehatan; SISKOHATKES) 2018 and underwent treatment. This study excluded pilgrims with incomplete data, having lung disease other than $T B$, having CVD, having cognitive obstacle, declining to participate, or failed to the Hajj from the final health examination. The final health examination was done at Pondok Gede embarkation to ensure the pilgrims were eligible to do Hajj.

TB data were taken from SISKOHATKES 2018 including the $A 15.0$ to $A 19.9$ code based on $10^{\text {th }}$ revision of the International Classification of Diseases and Health Related Problems. Secondary data were including age, gender, residence condition, education, and occupation. Other data such as duration of treatment, side effects during treatment for pilgrims with TB, comorbid, household contact, physical examination, thorax X-ray, laboratory data, and sixminute walk test for the level of fitness data were acquired at the district health centers. Residential conditions were seperated into two groups; crowded (>200 persons/ha) and not crowded ( $\leq 200$ persons/ha). ${ }^{7}$ Based on the authors' clinical judgment, side effects of the TB treatment were categorized into: nothing (no symptoms with normal laboratory findings); mild (tolerable abnormal findings and does not interfere with the organic function: e.g. no symptoms, but ALT/AST level shows an increase twice the normal level); moderate (intolerable abnormal findings but does not interfere with the organic functions: e.g. patient complaints of nausea and vomits but can be resolved by anti emetic drugs, ALT/AST level shows an increase twice the normal level, no changes in TB drug regimens); and severe (intolerable abnormal findings and does interfere with the organic functions: e.g. patient complaints of jaundice and vomiting which needs the changes of TB drug regimens). Body mass index (BMI) categorization used the standard from the World Health Organization: $<18.5 \mathrm{~kg} / \mathrm{m}^{2}$ (underweight); 18.5 to $<25 \mathrm{~kg} / \mathrm{m}^{2}$ (normal); 25 to $<30$ $\mathrm{kg} / \mathrm{m}^{2}$ (overweight); $30 \mathrm{~kg} / \mathrm{m}^{2}$ or higher (obese). ${ }^{8}$ Hemoglobin level of $13 \mathrm{gr} / \mathrm{dl}$ and above in men and 12 $\mathrm{gr} / \mathrm{dl}$ and above in women were categorized to normal group and otherwise lesser values were considered low. Level of $\mathrm{VO}_{2}$ max was categorized to $\leq 28 \mathrm{ml} / \mathrm{kgBB} /$ $\min$ (very poor), $>28$ to $34 \mathrm{ml} / \mathrm{kgBB} / \mathrm{min}$ (poor), $>34$ to $42 \mathrm{ml} / \mathrm{kgBB} / \mathrm{min}$ (enough), and $>42$ to $52 \mathrm{ml} / \mathrm{kgBB} / \mathrm{min}$ (good). Fitness levels were categorized based on $\mathrm{VO}_{2}$ max level, in which $\mathrm{VO}_{2}$ max level of $\geq 34.1 \mathrm{gr} / \mathrm{dl}$ was considered "fit" and otherwise was considered "not fit". 
Figure 1. Subject selection. SISKOHATKES=The Hajj Integrated Computer Health System; ICD-10=10th revision of the International Classification of Diseases and Health Related Problems; $\mathrm{TB}=$ tuberculosis; $\mathrm{MDR}=$ =multidrug resistance
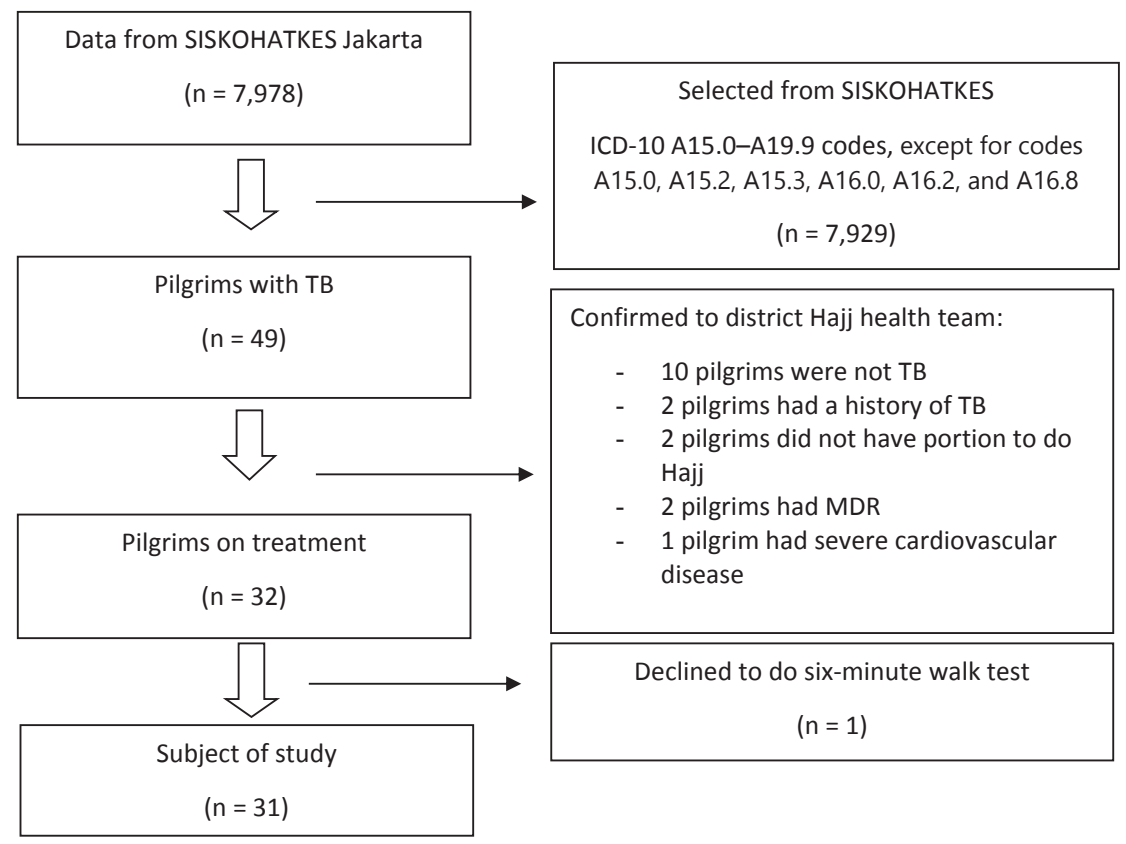

Additional data were collected from the Indonesian Hajj Health Team by answering a questionnaire. The questions included the emergence of symptoms of respiratory tract infection and the ability of pilgrims to perform congregational prayers at the Haram/Nabawi Mosque, during the recitation, Sa'i, throwing jumrah, staying overnight (Mabit) at Muzdalifah and Mina, and before staying in the area of Arafat. The instruction on how to fill the questionnaire was explained before the Hajj and filled after completing the pilgrimage. Data were recorded in research form and encoded with SPSS software version 23.0 for windows.

\section{RESULTS}

This study included 31 pilgrims after thorough screening as shown in Figure 1. Table 1 presents subjects' characteristics with most of TB cases confirmed with clinical confirmation. Pilgrims with normal chest radiographs were reconfirmed with positive molecular rapid test results. No pilgrims with treatment duration less than 2 months in this population flied for the Hajj. Most of pilgrims did not experience side effects of the treatment. Twenty-two subjects were identified with comorbidities, and some subjects had more than one comorbidities. The range value of $\mathrm{VO}_{2}$ max in this study was between $19.3 \mathrm{ml} /$ $\mathrm{kgBB} / \mathrm{min}$ and $46.5 \mathrm{ml} / \mathrm{kgBB} / \mathrm{min}$, with the average distance of pilgrims with TB was $381.3 \mathrm{~m}$ in men and
$335.5 \mathrm{~m}$ in women. $\mathrm{VO}_{2}$ max values were mostly poor with normal hemoglobin $(\mathrm{Hb})$ levels.

Data from one congregation could not be filled with questionnaires because the Hajj officer lost contact with them so that only data from 30 subjects had been obtained (Table 2). Most pilgrims were able to perform congregational prayers at the Haram Mosque, Nabawi Mosque, Tawaf, and Sa'i (26/30 = $87 \%$ ). All pilgrims were able to do their stay at Arafat and Mabit in Muzdalifah and Mina even though a small number of pilgrims required medical assistance $(2 / 30=$ $7 \%)$. Most of the jumrah throwing was able to be carried out independently by most pilgrims (80\%), while the remaining pilgrims were unable to do so and were represented instead.

\section{DISCUSSION}

The subjects in this study were pilgrims who had different characteristics from TB patients in the general population. Despite meeting the health requirements, the subjects were found to have asymptomatic TB infection. Additionally, given the long waiting period for people in Indonesia to undertake the Hajj, which could take between 11 and 29 years, the subjects were old, between 51 and 60 years old, when they were undertaking the Hajj.

TB in Indonesia according to Data and Information Center Ministry of Health Republic of Indonesia (Infodatin) 2018, stated that the new cases 
Table 1. Characteristics of research subjects

\begin{tabular}{|c|c|}
\hline Variable & $n(\%)(N=31)$ \\
\hline Male gender & $19(61)$ \\
\hline Age (years), median (min-max) & $59(27-80)$ \\
\hline 40 & $1(4)$ \\
\hline$<40-59$ & $15(48)$ \\
\hline$\geq 60$ & $15(48)$ \\
\hline \multicolumn{2}{|l|}{ Education } \\
\hline Elementary school & $5(16)$ \\
\hline Junior high school & $9(29)$ \\
\hline Senior high school & $4(13)$ \\
\hline Diploma & $4(13)$ \\
\hline Bachelor/Master degree & $9(29)$ \\
\hline \multicolumn{2}{|l|}{ Occupation } \\
\hline Housewife & $8(26)$ \\
\hline Private employees & $6(19)$ \\
\hline Government employees & $6(19)$ \\
\hline Retired & $4(13)$ \\
\hline Others & $7(23)$ \\
\hline \multicolumn{2}{|l|}{ Residence conditions } \\
\hline Crowded & $10(32)$ \\
\hline Not crowded & $21(68)$ \\
\hline \multicolumn{2}{|l|}{ Type of TB } \\
\hline Confirmed by microbiologic & $14(45)$ \\
\hline Confirmed by clinical & $17(55)$ \\
\hline \multicolumn{2}{|l|}{ The results of sputum } \\
\hline Negative & $10(32)$ \\
\hline Positive & $9(29)$ \\
\hline Not done & $12(39)$ \\
\hline \multicolumn{2}{|l|}{ Thorax feature } \\
\hline Bilateral lung involvement & $7(23)$ \\
\hline Unilateral lung involvement & $23(74)$ \\
\hline Normal & $1(3)$ \\
\hline \multicolumn{2}{|l|}{ Duration of treatment (month) } \\
\hline $2-6$ & $18(58)$ \\
\hline$>6$ & $13(42)$ \\
\hline Repeated TB treatment & $3(10)$ \\
\hline \multicolumn{2}{|l|}{ Severity of TB treatment side effect } \\
\hline Nothing & $23(74)$ \\
\hline Mild & $5(16)$ \\
\hline Moderate & $1(3)$ \\
\hline Severe & $2(7)$ \\
\hline Body mass index $\left(\mathrm{kg} / \mathrm{m}^{2}\right)$, median (min-max) & $23(16-33)$ \\
\hline Underweight & $3(10)$ \\
\hline Normal & $20(64)$ \\
\hline Overweight & $5(16)$ \\
\hline Obese & $3(10)$ \\
\hline
\end{tabular}

Table 1. (continued)

\begin{tabular}{lc}
\hline Variable & $\mathrm{n}(\%)(\mathrm{N}=31)$ \\
\hline Charlson comorbidity index & $9(29)$ \\
\hline 0 & $13(42)$ \\
\hline 2 & $7(23)$ \\
\hline 3 & $2(6)$ \\
Hemoglobin level, median (min-max) & 13.6 \\
\hline Normal & $(10.6-16.4)$ \\
\hline Less than normal & $26(84)$ \\
VO max, median (min-max) & $5(16)$ \\
\hline Very poor & 32.5 \\
Poor & $(19.3-46.5)$ \\
\hline Enough & $6(19)$ \\
Good & $13(42)$ \\
\hline Fitnesses & $10(32)$ \\
\hline Not fit & $2(7)$ \\
\hline & $12(39)$ \\
\hline & $191)$ \\
\hline
\end{tabular}

$\mathrm{TB}=$ tuberculosis; $\mathrm{VO}_{2}$ max=maximal oxygen consumption

of TB in 2017 is 1.4 times higher in men than women. This is possible because men are more exposed to the risk of TB due to factors that can damage lung integrity such as smoking and lack of compliance with medication. About 10 of 31 subjects live in densely populated areas. High levels of urbanization and increased indoor air pollution contributes to TB transmission. Thus, it increases damage to the lung and enhances possibility of TB infection..$^{5,9}$ Most of subjects in this study had normal body mass index (BMI). This is not in accordance with other studies stating that active TB were higher in low BMI as well as a decrease in immune system group. ${ }^{10}$ However, pilgrims are required to have a healthy body, supported by endurance and strength, which is correlated with good BMI. ${ }^{6}$

Most of the subjects in this study did not complain any symptoms of TB at the beginning of the examination (93.5\%). Confirmation of acid-fast bacilli (AFB) test in some pilgrims could not be done due to the absence of sputum samples. The decision to do therapy was also confirmed by the Xpert MTB/ RIF assay on some pilgrims. None of the subjects in this study had undergone treatment for less than 2 months. Therefore, all subjects are in a continuation phase or MDR treatment. In this continuation phase, 
Table 2. The ability of the Hajj pilgrims with TB to undertake the Hajj

\begin{tabular}{|c|c|}
\hline Variable & $\mathrm{n}(\%)(\mathrm{N}=30)$ \\
\hline \multicolumn{2}{|c|}{$\begin{array}{l}\text { The emergence of respiratory tract } \\
\text { infections in Saudi Arabia }\end{array}$} \\
\hline No & $19(63)$ \\
\hline Yes & $11(37)$ \\
\hline \multicolumn{2}{|c|}{ Prayer ability in congregation at the mosque } \\
\hline Able & $26(86)$ \\
\hline Need help & $2(7)$ \\
\hline Not able at all & $2(7)$ \\
\hline \multicolumn{2}{|l|}{ Tawaf } \\
\hline Able & $26(87)$ \\
\hline Need help & $4(13)$ \\
\hline Not able at all & $0(0)$ \\
\hline \multicolumn{2}{|l|}{$S a^{\prime} i$} \\
\hline Able & $26(87)$ \\
\hline Need help & $4(13)$ \\
\hline Not able at all & $0(0)$ \\
\hline \multicolumn{2}{|l|}{ Wukuf in Arafat } \\
\hline Able & $28(93)$ \\
\hline Need help & $2(7)$ \\
\hline Not able at all & $0(0)$ \\
\hline \multicolumn{2}{|c|}{ Mabit in Muzdalifah } \\
\hline Able & $28(93)$ \\
\hline Need Help & $2(7)$ \\
\hline Not able at all & $0(0)$ \\
\hline \multicolumn{2}{|l|}{ Mabit in Mina } \\
\hline Able & $28(93)$ \\
\hline Need help & $2(7)$ \\
\hline Not able at all & $0(0)$ \\
\hline \multicolumn{2}{|l|}{ Throwing jumrah } \\
\hline Able & $24(80)$ \\
\hline Need help & $3(10)$ \\
\hline Not able at all & $3(10)$ \\
\hline
\end{tabular}

subjects had experienced AFB smear conversion. Both of them which initially had positive smear sputum and negative smear, would give negative evaluation results. Likewise, two treated MDR patients, had Xpert MTB/RIF assay negative results and a decision from the MDR-TB Clinical Team had been issued for the pilgrimage. ${ }^{11}$

Most of subjects did not experience side effects from TB treatment. The most common side effect was an allergic reaction in the forms of irritating itch and rash on the skin. Neurological disorders were also reported by two MDR patients in the form of headaches, spinning dizziness, hearing loss, and tingling and numbness in the extremities.

Chronic comorbidity included advanced hypertension (9/31; 29\%) and diabetes mellitus (8/31; $26 \%$ ), and some subjects had more than one comorbid chronic diseases. Most pilgrims had normal $\mathrm{Hb}$ levels (26/31; 84\%). Although some pilgrims had Hb level below the standard reference range, they were still able to do the Hajj if $\mathrm{Hb}>9.5 \mathrm{~g} / \mathrm{dl}$. A study reported that $\mathrm{Hb}$ could affect the fitness levels with average $\mathrm{Hb}$ of the subjects is $10.1 \mathrm{~g} / \mathrm{dl}$ in men and $10 \mathrm{~g} / \mathrm{dl}$ in women. ${ }^{12}$

Results of fitness assessments showed that $61 \%$ subject was not eligible, with $\mathrm{VO}_{2}$ max values poor (13/31; 42\%) and very poor (6/31; 19\%). Evaluation of fitness results recommendations was not carried out in this study. A study by Nusdwinuringtyas ${ }^{13}$ in 123 subjects ( 58 male, 65 female) concluded that the mean prediction of mileage in male subjects was $581.98 \mathrm{~m}$, while the mean in female subjects was $516.80 \mathrm{~m}$. Actual mileage is considered normal when $>483 \mathrm{~m}$ in male subjects and $>442$ in female subjects. In this study, the results of the average distance of pilgrims with TB was $381.3 \mathrm{~m}$ in men and $335.5 \mathrm{~m}$ in women. However, based on the average age, Nusdwinuringtyas' study ${ }^{13}$ involved samples with an average age of men 26.78 years and women 21.92 years without comorbidities, whereas this study was dominated by age $>40$ years and with comorbidities.

Data collected from the Indonesian Hajj Health Team which accompanied the research subjects showed that the research subjects were able to carry out the pillars of the Hajj and did not have to repeat the pilgrimage. In carrying out the pilgrimage, there are pillars of pilgrimage and obligatory pilgrimage. There are six pillars of pilgrimage namely intention for Ihram, Tawaf, Sa'i, Wukuf in Arafat, Tahalul, and orderly. If there is one pillar that is not carried out, the pilgrimage is invalid and must be repeated. Obligatory pilgrimage is a number of things in the Hajj, which if it cannot be done, it does not affect the validity of the Hajj, and those who leave it can replace it with dams (fines). The mandatory Hajj are Mabit in Muzdalifah, throwing aqabah jumrah seven times, throwing three jumrah on Tasyriq (11, 12, and 13 Dhu al-Hijjah), Mabit on eve of Tasyriq, Ihram of Miqat, and Tawaf Wada.

However, some subjects cannot undertake all of them independently, and must be assisted in their worship. At Tawaf and Sa'i, $13 \%$ of the subjects needed 
help, and $7 \%$ of the subjects needed help when staying in the Arafat. In undertaking the obligatory pilgrimage, subjects were able to spend the night in Muzdalifah and Mina, although 7\% needed to be assisted, and some subjects were unable to stone the Jamarat (10\%), but this obligation can be done by other family members and did not affect the validity of the Hajj. ${ }^{14}$

From these data, some pilgrims with TB and declared eligible to the Hajj with istithaah Requirements with Assistance with lack of fitness level were still able to carry out the pillars of pilgrimage, but could not do the obligatory pilgrimage perfectly. Therefore, the examination of fitness tests for the pilgrims should be re-evaluated after intervention to improve fitness during the waiting period. Existing training recommendations from the District Hajj Health Teams need to be carried out in a measurable way to see the improvement of the level of fitness so that the final results of the promotive and preventive efforts can support the pilgrims to perform the Hajj pilgrimage optimally in the holy land.

This study is one of the first studies which involved pilgrims with TB and their fitness level, using gradual confirmation as a study method. The samples were also representative from all regions in Jakarta. Subject home visits and visits to the Jakarta embarkation were also carried out. The results of this study are able to reinforce the Minister of Health's Regulation No. 15/2016 regarding the importance of health on the istithaah limitations of TB patients on the Hajj, and provide informations in increasing the success of promotive, preventive, curative, and rehabilitative efforts in carrying out the Hajj. However, this study could not explain the temporal relationship between factors studied due to its study design. The number of research samples obtained from pilgrims in Jakarta also cannot represent the prevalence of pilgrims with TB in Indonesia, so further research needs to be done involving other Hajj embarkations in Indonesia. Thus, a follow-up nationwide study is needed to make the study result more applicable.

In conclusion, subjects who had completed the intensive phase treatment with negative smear sputum or MDR-TB were declared eligible to the Hajj with istithaah Requirements with Assistance. As many as $61 \%$ of the Hajj pilgrims with TB had a level of fitness below sufficient value. Nevertheless, all subjects were still able to run the pillars of the Hajj.

\section{Conflict of Interest}

The authors affirm no conflict of interest in this study.

\section{Acknowledgment}

Authors thank Prof. Aru, Dr. dr. Aida lydia, Dr. dr. Dyah Purnamasari for their help in this study.

\section{Funding Sources}

We thank PITTA Grant Universitas Indonesia for the help of support this study.

\section{REFERENCES}

1. Al-Orainey IO. Tuberculosis infection during Hajj pilgrimage. The risk to pilgrims and their communities. Saudi Med J. 2013;34(7):676-80.

2. AlOtaibi SM, Almoshadq AF, Alghanmi HA, Aljuiad F, Soliman YR, Alzuair AT, et al. Poor knowledge of tuberculosis among the population of Jeddah and Makkah Saudi Arabia, a high-risk area. Journal of Tuberculosis Research. 2016;4:81-91.

3. Indonesian Hajj Health Center, Ministry of Health of the Republic of Indonesia. 2016 Hajj health center performance report. Jakarta: Ministry of Health of the Republic of Indonesia; 2016. Indonesian.

4. Abouzeid MS, Zumla AL, Felemban S, Alotaibi B, O'Grady J, Memish ZA. Tuberculosis trends in Saudis and non-Saudis in the Kingdom of Saudi Arabia-a 10 year retrospective study (20002009). PloS One. 2012;7(6):e39478.

5. Pane M, Imari S, Alwi Q, Kandun IN, Cook AR, Samaan G. Causes of mortality for Indonesian Hajj pilgrims: comparison between routine death certificate and verbal autopsy findings. PloS One. 2013;8(8):e73243.

6. Ministry of Health of the Republic of Indonesia. The Ministry Decree No 15 Year 2016 concerning Hajj health istithaah. Jakarta: Ministry of Health of the Republic of Indonesia; 2016. Indonesian.

7. Ismail Z. Penanggulangan Kemiskinan Masyarakat Perkampungan Kumuh di Yogyakarta: Kasus Kelurahan Keparakan. 2006. Jakarta: Puslitbang Ekonomi dan Pembangunan Lembaga Ilmu Pengetahuan Indonesia. Indonesian.

8. Obesity: preventing and managing the global epidemic. Report of a WHO consultation. World Health Organ Tech Rep Ser. 2000; 894:1-253.

9. Gardouni A. The Mecca pilgrimage and its medical preparedness. Athens: National and Kapodistrian University of Athens; 2012

10. Casha AR. Scarci M. The Link between Tuberculosis and Body Mass Index. J Thorac Dis. 9, 301-3. 2017.

11. World Health Organization Indonesia. Indonesia TB situation 2017 [Internet]. 2018 [cited 2018 Apr 14]. Jakarta: World Health Organization Indonesia. Available from: http://origin.searo.who. int/indonesia/topics/tb/IndonesiaTBSituation2017/en/.

12. Bhakare PS, Vaishnav DM, Irani, F. A study of effect of haemoglobin and body weight on $\mathrm{VO} 2$ max in young males and females. IJMTST. 2013;9:243-4.

13. Nusdwinuringtyas N. Six minute walking distance cut-off point in Indonesian (mongoloid) population. J Indon Med Assoc, 2018;68(8):389-94

14. Sabiq S. Fiqih sunnah: Haji Rasulullah SAW. Jakarta; 2017. p. 1-32. 